\title{
Schistosoma mansoni: INFLAMMATORY FOCI AROUND LARVAE IN THE PERITONEAL CAVITY OF NAIVE MICE IS RADIOSENSITIVE
}

\author{
Alan Lane de MELO(1) \& Munir CHAMONE(2)
}

\begin{abstract}
SUMMARY
Innate attack to Schistosoma mansoni cercariae was evaluated in irradiated mice. It was observed that $70 \%$ of the larvae from mice sacrificed one day after whole body irradiation with 400 or 800 rads were surrounded by cluster reactivities, without difference from controls. Differences were apparent on day 5 after irradiation with sub lethal (400 rads) or lethal doses (800 rads) suggesting that innate defence to infection take at least 5 days to be affected by low dose whole-body radiation.
\end{abstract}

KEYWORDS: Schistosoma mansoni; Cercariae; $\gamma$ Radiation; Peritoneal cavity.

\section{INTRODUCTION}

The suppression of cell reactivity in animals, following whole body radiation, is generally accepted as a suitable strategy for functional studies of host-parasite relationship. The expression of cutaneous resistance to Schistosoma mansoni depends upon the presence of radiosensitive cells, presumable eosinophils 7 . The whole body radiation protocols produce changes on worm burden ${ }^{1,2,5}$ or in a cell-mediated reaction in the host skin, lungs and blood $d^{1,2,5,7,20}$.

In addition to the classical site of attrition, the protection elicited via intraperitoneal route against parasitic worms had been demonstrated ${ }^{6,12}$.

Some studies have highlighted the macrophages or peritoneal cells as active role during $S$. mansoni infection by classical routes ${ }^{3,11}$ or the neutrophils as an example of the first line defence in a peritoneal cavity of mice model ${ }^{15,16}$. However, little attention has been done to wholebody irradiation protocols in, which are might expect disable innate peritoneal resistance in mice against $S$. mansoni compared with other radiation protocols ${ }^{13}$.

In previous in vivo experimental S. mansoni study ${ }^{15,16}$, it was found that intraperitoneal injections of cercariae into naive mice caused a cell interaction (including cluster reactions) to the infective larvae. However, there have been no investigations on cluster of cell reactivity ${ }^{12,15}$ following total body $\gamma$-irradiation. Herein, these points were pursued.

\section{MATERIAL AND METHODS}

Swiss mice (males, weighing 18-22 g) received an intraperitoneal inoculation with about 500 Schistosoma mansoni cercariae (LE strain) shed by laboratory reared and infected Biomphalaria glabrata (Belo Horizonte strain), 24 and 120 hours after exposition to whole body $\gamma$ irradiation (400 or 800 rads). Unexposed mice were used as controls.

Groups of five mice were killed by cervical dislocation 30 and 180 minutes after cercarial inoculation. The larvae were collected by washing the peritoneal cavity with saline, and were concentrated by centrifugation as described previously ${ }^{14}$. The recovered larvae were resuspended in 1 $\mathrm{ml}$ of saline solution and examined under a dissecting stereomicroscope. The number of larvae (tailed or tailless), with or without adherent host cells was counted. The mean percentage (standard deviation) of larvae with or without adhered cells was calculated. Cells and parasites obtained from each peritoneal cavity were used to prepare smears and some of them received drops of $0.1 \%$ neutral red solution or were stained by Giemsa or Wrigth's stains ${ }^{14}$.

\section{RESULTS}

As shown in Table 1, cell adhesions to the larvae were observed in both the exposed and unexposed groups of animals.

It was observed that recovered larvae were partially or completely surrounded by leukocytes or yet were trapped in large cellular coagulates. This is referred as a cluster of cell reactivity.

As a general rule, cells were firmly adhered to the organisms and were not easily dislodged during the smear preparation. Sometimes single cells adhered to schistosomula-like organisms (tailless cercariae), but clumps of adherent cells were more often seen. A total coverage of the cercaria with adherent cells was not uncommon. Most cells were attached to the parasite tail.

Supported by The Parasitic Diseases Programme - WHO, Switzerland, CNPq, FINEP, and FAPEMIG, Brazil.

(1) Departamento de Parasitologia, Instituto de Ciências Biológicas da UFMG. CP 486, 30161-970 Belo Horizonte, MG, Brasil.

(2) Departamento de Bioquímica e Imunologia, Instituto de Ciências Biológicas da UFMG. CP 486, 30161-970 Belo Horizonte, MG, Brasil.

Correspondence to: A.L.M: aldemelo@icb.ufmg.br 
Table 1

Percentual recovery of Schistosoma mansoni larvae with cell adhesion from peritoneal cavity of naive mice, submitted to 400 and 800 rads 24 and 120 hours before cercariae inoculation

\begin{tabular}{lccc}
\hline Dose & $\begin{array}{c}\text { Period before } \\
\text { cercarial } \\
\text { inoculation } \\
\text { Hours }\end{array}$ & \multicolumn{2}{c}{$\begin{array}{c}\text { Percents of larvae with cell } \\
\text { adhesion recovered from } \\
\text { peritoneal cavity }\end{array}$} \\
\cline { 2 - 4 } Control & 24 & $71.9 \pm 3.2$ & $2.7 \pm 3.7$ \\
& 120 & $70.2 \pm 9.6$ & $1.6 \pm 1.2$ \\
400 rads & 24 & $72.1 \pm 2.5$ & $0.6 \pm 0.8$ \\
& 120 & $32.4 \pm 5.2$ & $0.4 \pm 0.8$ \\
800 rads & 24 & $70.2 \pm 3.6$ & $0.0 \pm 0.0$ \\
& 120 & $27.0 \pm 2.8$ & $0.5 \pm 1.0$ \\
\hline
\end{tabular}

Mean and SD of percentage from 2 isolated experiments with 5 animals each.

The outer layer of cells over the larvae showed a single nucleus, various amounts of extra nuclear cytoplasm stained by neutral red, which constitute a characteristic of the monocytic series. It was observed that about $70 \%$ of the larvae from mice sacrificed one day after whole body irradiation with 400 or 800 rads were surrounded by cluster reactivities, without difference from controls. Differences were apparent when intraperitoneal inoculation was carried out on day 5 after irradiation with sub lethal (400 rads) or lethal doses (800 rads). Among animals that received 400 rads, cells surrounded about $32 \%$ of larvae, and in mice irradiated with 800 rads, near $27 \%$ of larvae showed cell adhesion, with a few cells adhered to the larvae and no evident cluster as observed in control mice (against about $70 \%$ of controls).

\section{DISCUSSION}

There are conflicting reports concerning the effect of irradiation given in vivo on micro - organism handling by mouse macrophages. While some claim that macrophages of irradiated mice are unable to kill or retain bacteria ${ }^{10}$, others report that sub lethal doses (550 rads) damage the capacity of macrophages to process the Shigella paradisenteriiae antigen ${ }^{8}$ and yet in contrast, certain mice in which is given lethal doses of radiation, an increase of the intracellular digestion of erythrocytes by mouse peritoneal macrophages were observed ${ }^{17,18}$. In addition the activated peritoneal macrophages were more active than normal controls against infection by the facultative intracellular Brucella abortus and Listeria monocytogenes ${ }^{4}$.

In the present study it was observed that innate defence to $S$. mansoni infection takes at least 5 days to be affected by low dose whole-body radiation, suggesting the involved cells have short half-life and practically they disappear after $\gamma$-irradiation.

As differences in protocols have been reported in literature, comparison of results is difficult. In fact, mice receiving 650 rads three days prior to the infection with cercariae infection showed no reduction in innate immunity as seen by lung cellular reaction foci, around $S$. mansoni larvae ${ }^{20}$. Similarly, mice receiving 650 rads five days prior to percutaneous cercariae infection plus transfer of normal or immune serum were not able to reduce innate immunity (as seen by the number of schistosomula recovered from lungs $)^{9}$. On the other side, a deleterious effect of whole body irradiation on the killing of intravenous injection of schistosomula was reported ${ }^{19}$.

In view of the present findings showing, by $\gamma$-irradiation, a reduction in the cluster of macrophage-like cells, variations in radiation effects should be taken into account in interpreting the results from in vivo experiments. Since several mechanisms that can operate in vitro, might not play a role in vivo resistance. The functional basis for the macrophagelike cluster abrogated by irradiation in mice is not known.

\section{RESUMO}

\section{Schistosoma mansoni: a reação inflamatória em torno da larva, na cavidade peritoneal de camundongos é sensível a radiação}

A defesa inicial do hospedeiro contra cercárias de Schistosoma mansoni foi avaliada em camundongos irradiados. Observou-se que cerca de $70 \%$ das larvas recuperadas de camundongos submetidos a doses de 400 ou 800 rads um dia antes da infecção apresentaram células aderidas. Diferenças significativas foram verificadas no $5^{\circ}$ dia após a irradiação sugerindo que a defesa incial do hospedeiro demora pelo menos 5 dias para ser afetada por irradiação gama.

\section{REFERENCES}

1. AITKEN, R.; COULSON, P.S.; DIXON, B. \& WILSON, R.A. - Radiation-resistant acquired immunity of vaccinated mice to Schistosoma mansoni. Amer. J. trop. Med. Hyg., 37: 570-577, 1987.

2. AITKEN, R. \& WILSON, R.A. - The growth and development of Schistosoma mansoni in mice exposed to sublethal doses of radiation. J. Parasit., 75: 958-963, 1989.

3. CHAO, L.P.; JONES, J.T. \& KUSEL, J.R. - An in vivo model for the study of chemotaxis induced by schistosomula of Schistosoma mansoni. Parasitology, 92: 117-132, 1986.

4. CHEERS, C. \& WALLER, R. - Activated macrophages in congenitally athymic "nude mice" and lethally irradiate mice. J. Immunol., 115: 844-847, 1975.

5. CHEEVER, A.W. \& DUVALL, R.H. - Variable maturation and oviposition by female Schistosoma japonicum in mice: the effects of irradiation of the host prior to infection. Amer. J. trop. Med. Hyg., 37: 562-569, 1987.

6. COULSON, P.S. \& MOUNTFORD, A.P. - Fate of attenuated schistosomula administered to mice by different routes relative to the immunity induced against $S$. mansoni. Parasitology, 99: 39-45, 1989.

7. DELGADO, V.S. \& McLAREN, D.J. - Evidence that radio-sensitive cells are central to skin-phase protective immunity in CBA/Ca mice vaccinated with radiation-attenuated cercariae of Schistosoma mansoni as well as in naïve mice protected with vaccine serum. Parasitology, 100: 45-56, 1990.

8. GALLILY, R. \& FELDMAN, M. - The role of macrophages in the induction of antibody in X - irradiated animals. Immunology, 12: 197-206, 1967.

9. GOES, A.M. \& RAMALHO-PINTO, F.J. - Protective immunity to Schistosoma mansoni in mice is dependent on antibody and complement but not on radiosensitive leukocytes. Immunol. Lett., 28: 57-63, 1991.

10. GORDON, L.E.; RUML, D.; HAHNE, H.J. \& MILLER, C.P. - Studies on susceptibility to infection following ionising radiation. IV. The pathogenesis of the endogenous bacteremias in mice. J. exp. Med., 102: 413-424, 1955. 
11. JAMES, S.L. - Induction of protective immunity against Schistosoma mansoni by a nonliving vaccine. III. Correlation of resistance with induction of activated larvacidal macrophages. J. Immunol., 136: 3872-3877, 1986.

12. JESKA, E.L. - Mouse peritoneal exudate cell reactions to parasitic worms. 1. Cell adhesion reactions. Immunology, 16: 761-771, 1969.

13. KAMBARA, T. \& WILSON, R.A. - In situ pulmonary responses of T cell and macrophage subpopulations to a challenge infection in mice vaccinated with irradiated cercariae of Schistosoma mansoni. J. Parasit., 76: 365-372, 1990.

14. MELO, A.L. de \& PEREIRA, L.H. - Kinetics of the cercaria-schistosomulum transformation, in vivo. Rev. Soc. bras. Med. trop., 18: 17-21, 1985.

15. MELO, A.L. de; MACHADO, C.R.S. \& PEREIRA, L.H. - Host cell adhesion to Schistosoma mansoni larvae in the peritoneal cavity of naive mice. Histological and scanning electron microscope studies. Rev. Inst. Med. trop. S. Paulo, 35: 17 $22,1993 \mathrm{a}$
16. MELO, A.L. de; MACHADO, C.R.S. \& PEREIRA, L.H. - Interaction between neutrophils and Schistosoma mansoni larvae in vivo. A transmission electron microscopic study. Rev. Inst. Med. trop. S. Paulo, 35: 29-33, 1993b.

17. PERKINS, E.H. \& MARCUS, S. - The effect of X - radiation on preformed antibody and its role in the protection of X - irradiated mice. J. infect. Dis., 102: 81-87, 1958.

18. PERKINS, E.H.; NETTESHEIM, P. \& MORITA, T. - Radioresistance of the engulfing and degradative capacities of the peritoneal phagocytes to kiloroentgen X-ray doses. J. reticuloendoth. Soc., 3: 1-71, 1966.

19. SHER, A. - Immunity against Schistosoma mansoni in the mouse. Amer. J. trop. Med. Hyg., 26: 20-28, 1977.

20. VIGNALI, D.A.; BICKLE, Q.D. \& TAYLOR, M.G. - Studies on immunity to Schistosoma mansoni in vivo: whole-body irradiation has no effect on vaccine- induced immunity in mice. Parasitology, 96: 49-61, 1988.

Received: 7 July 1999

Accepted: 13 November 2000 